Review

\title{
The role of long non-coding RNAs in nasopharyngeal carcinoma: As systemic review
}

\author{
Rongzhang $\mathrm{He}^{1, *}$, Zheng Hu ${ }^{1,2, *}$, Qingmei Wang ${ }^{1,3}$, Weihao Luo ${ }^{1}$, Jia $\mathrm{Li}^{1}$, Lili Duan ${ }^{1}$, \\ Yuan-shan Zhu ${ }^{1,2}$, Di-xian Luo ${ }^{1,3}$ \\ ${ }^{1}$ Translational Medicine Institute, National \& Local Joint Engineering Laboratory for High-through Molecular Diagnosis \\ Technology, Collaborative Research Center for Post-doctoral Mobile Stations of Central South University, Affiliated the First \\ People's Hospital of Chenzhou of University of South China, Chenzhou 432000, P.R. China \\ ${ }^{2}$ Department of Clinical Pharmacology, Xiangya Hospital and Institute of Clinical Pharmacology, Central South University and \\ Hunan Key Laboratory of Pharmacogenetics, Changsha, Hunan 410078, P. R. China \\ ${ }^{3}$ Center for Clinical Pathology, Affiliated the First People's Hospital of Chenzhou, University of South China, Chenzhou 432000, \\ P.R. China \\ *These authors have contributed equally to this work \\ Correspondence to: Di-xian Luo, email: Ivodixian_2@163.com
}

Keywords: nasopharyngeal carcinoma (NPC), IncRNAs, tumorigenesis, therapeutic targets, biomarker

Received: September 20, 2016

Accepted: November 23, 2016

Published: December 26, 2016

\section{ABSTRACT}

Recent development of cutting edge research found that long noncoding RNAs (IncRNAs) plays important roles in carcinogenesis and progression. In Southeast Asia and North Africa, nasopharyngeal carcinoma (NPC) is the most common aggressive squamous cell carcinoma. Nasopharyngeal carcinoma is most frequently occurring in males. However, nasopharyngeal carcinoma is caused by a combination of several factors as viral, environmental factors, and heredity. Till now, the potential pathway or mechanism of NPC is not well known. In our present review, we strongly emphasized on long noncoding RNAs (IncRNAs) and its significant role in nasopharyngeal carcinoma. It has been showed that IncRNAs regulate the development and progression of different types of cancers, including NPC. In addition, it has been found that chromatin organization, transcriptional and post-transcriptional events are regulated by IncRNAs. Our present review summarizes the roles of IncRNAs in nasopharyngeal carcinoma and provides an overview of the feasibility of IncRNAs as diagnosis, prognosis and potential treatment for NPC patients.

\section{INTRODUCTION}

Nasopharyngeal carcinoma (NPC) is the most common squamous cell carcinoma involving epithelial lining of the nasopharynx. Nasopharyngeal carcinoma is predominant in North Africa and in South-east Asia, especially in China [1]. In addition, the incidence of NPC in western countries is very rare, almost less than $1 / 100,000$. But in China, NPC is highly prevalent with an incidence of 20/100,000. In China, the new NPC case increases exponentially as sixty thousand new NPC cases were reported in 2015 [2]. Development and progression of NPC involves genetic susceptibility, environmental or stochastic factors and Epstein-Barr virus (EBV) infection. However, in nasopharyngeal carcinoma, EBV functions as a surrogate biomarker. Moreover, the recommended treatment for NPC is radiotherapy, in combination with chemotherapy
[1]. However, after curative treatment by radiotherapy in combination with chemotherapy, no big improvement in the overall survival rate of NPC patients has been observed [3]. Therefore, in order to develop a curative treatment, it is most required to understand the molecular mechanisms underlying nasopharyngeal carcinoma [4]. Additionally, advancement of the high-throughput technologies allows us to concentrate on research of the lncRNAs.

LncRNAs are non-protein coding transcripts with $>200$ nucleotides and located in nuclear or cytosolic fractions. It has been showed that the quantity of lncRNAs and the quantity structural gene are same in human genome [5]. Several supporting evidences have shown that the dysregulated lncRNAs has a significant role in nasopharyngeal cancers [6-10].

In this review, we illustrate and discuss the recent advancement in research of lncRNAs and its significant 
role in NPC. The potential role of lncRNAs as biomarkers for NPC and diagnosis or therapeutic target for NPC treatment is discussed in detail.

\section{CLASSIFICATION OF LNCRNAS}

LncRNAs are non-protein coding transcripts with a length between $200 \mathrm{bp}$ to $10 \mathrm{~kb}$ [11]. On the basis of the GENCODE annotation, lncRNAs are categorized into five classes, as follows; sense, antisense, pseudogene, intronic, and intergenic lncRNAs [5, 12, 13] (Figure 1)

Moreover, nearly, 98-99\% of human genome is nonprotein coding regions. However, several mechanisms for transcription activation regulate the intergenic lncRNAs and intronic lncRNAs [12]. Sense lncRNA and antisense lncRNA are most frequent among all classes of lncRNAs [13].

\section{DYSREGULATION OF LNCRNA IN NPC}

It has been reported that lncRNAs is playing key regulatory roles in chromosome modification [14], transcription and posttranscriptional modification $[15,16]$. We illustrate and provide an overview of the function of lncRNAs in the development of NPC (Figure 2). Here, we summarize all lncRNAs associated with NPC in Table 1.

\section{MALAT-1}

It is a non-protein coding RNA with 8,000 nucleotide, located at chromosome 11q13. In addition, Ji et al first reported that expression of MALAT1 increased in no-small cell lung cancer (NSCLC) and associated with metastasis in NSCLC [17].

(A) Intergenic

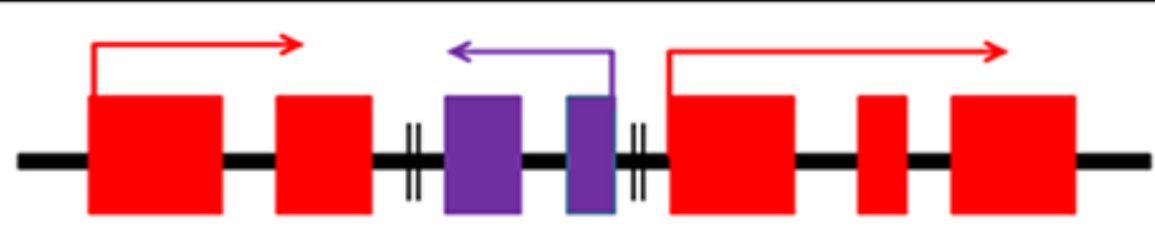

(B) Intronic

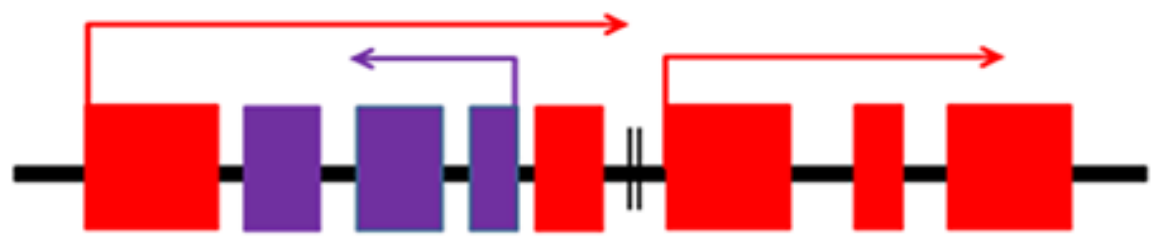

(C) Pseudogene

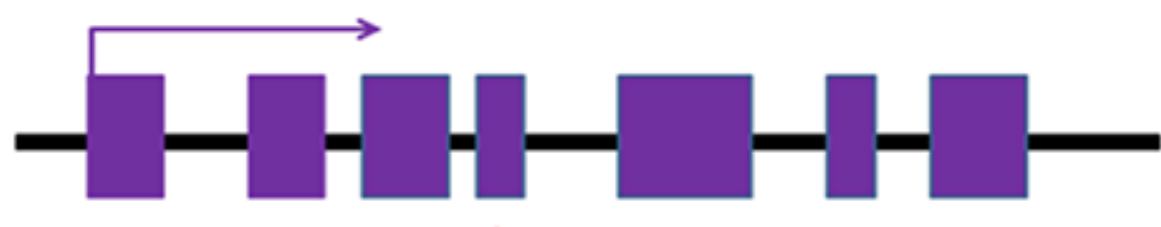

(D) Sense

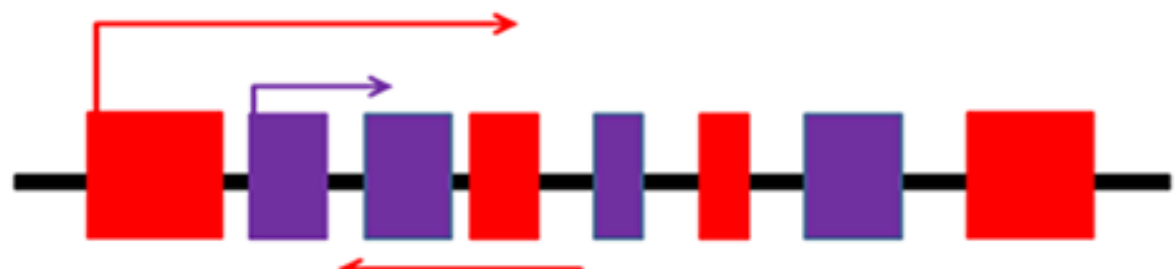

(E) Antisense

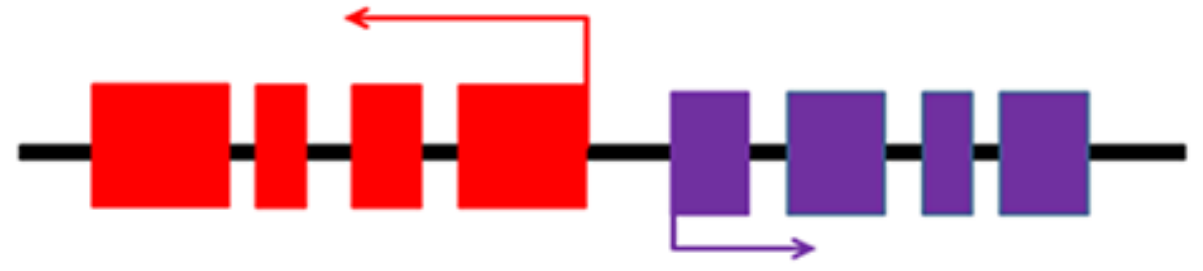

Coding

Noncoding

Figure 1: Overview of five broad categories of IncRNAs. A. Intergenic lncRNAs are transcribed form intergenic regions. B. Intronic lncRNAs are transcribed from introns of coding genes. C. Pseudogenes are the "relics" of genes that have lost their coding function because of mutations. D. Sense lncRNAs are transcribed from the sense strand of coding genes and overlaps with a protein-coding gene. E. Antisense lncRNAs are transbribed from the antisense strand of protein-coding genes. 
(A)

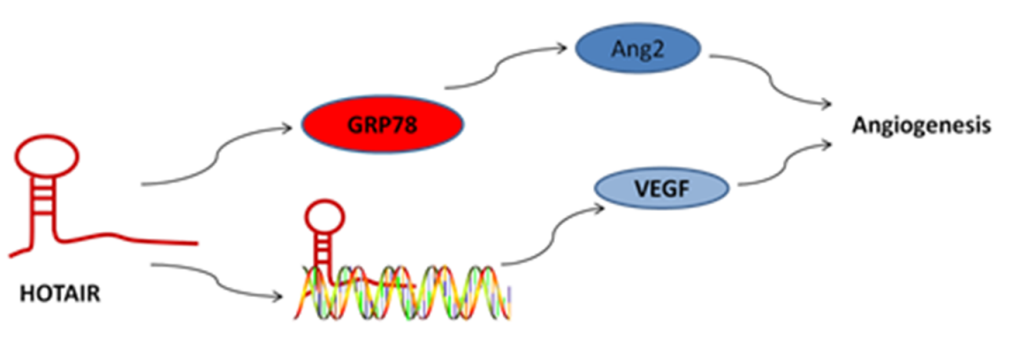

(B)

VEGF promoter

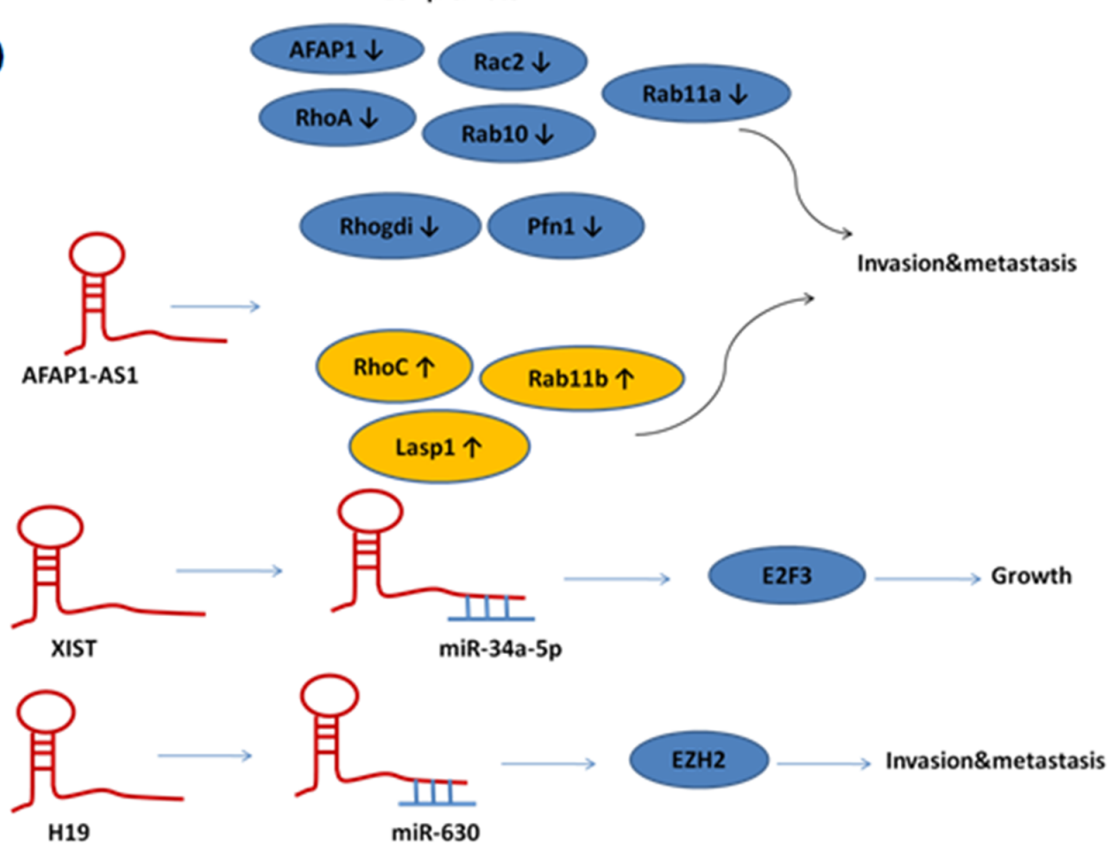

(C)

(D)

(E)

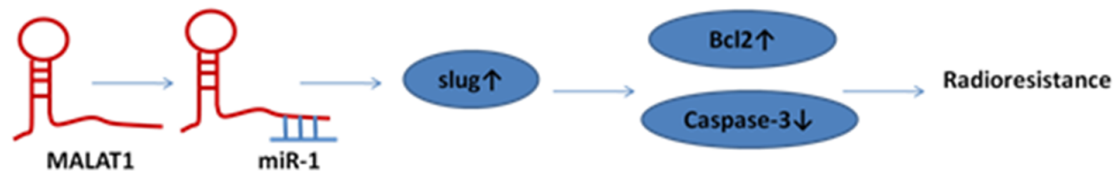

(F)

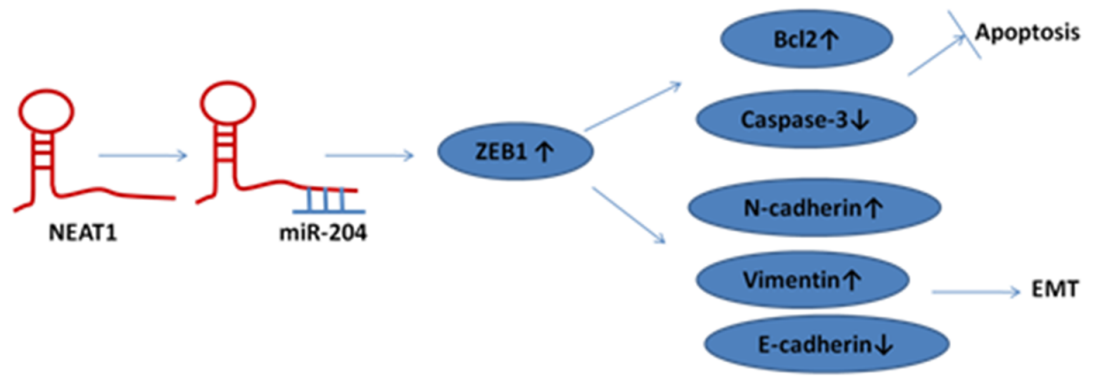

Figure 2: Functional mechanisms of IncRNAs in NPC. A. Hotair promoted angiogenesis through directly activating the transcription of angiogenic factor VEGFA as well as through GRP78-mediated upregulation of VEGFA and Ang2 expression. B. AFAP1-AS1 inhibits AFAP1 protein expression and affected the expression of several small GTPase family members and molecules in the actin cytokeratin signaling pathway. promoted cancer cell metastasis via regulation of actin filament integrity. C. XIST functioned as an oncogene in NPC through up-regulating E2F3 in part through 'spongeing' miR-34a-5p. D. H19 Inhibits E-cadherin expression and promoted invasion via the mir-630/EZH2 pathway. E. MALAT1 regulates CSC activity and radioresistance by modulating mir-1/slug axis. F. NEAT1 regulates EMT phenotype and radioresistance by modulatin themir-204/ZEB1 axis. 
Table 1: Roles and functions of IncRNAs in nasopharyngeal carcinoma

\begin{tabular}{|c|c|c|c|c|c|c|}
\hline IncRNA & Location & Expression & $\begin{array}{l}\text { Function in } \\
\text { tumorigenesis }\end{array}$ & Classification & Potential mechanism & Reference \\
\hline XIST & $\mathrm{Xq13}$ & Up & Oncogenic & Intergenic & $\begin{array}{l}\text { XIST functioned as an oncogene } \\
\text { in NPC through up-regulating } \\
\text { E2F3 in part through 'spongeing' } \\
\text { miR-34a-5p }\end{array}$ & {$[63]$} \\
\hline IncRNA-ROR & $18 \mathrm{q} 21$ & Up & Oncogenic & Intergenic & $\begin{array}{l}\text { Suppress p53 signal pathway and } \\
\text { promotes proliferation, migration } \\
\text { and chemoresistance }\end{array}$ & [69] \\
\hline AFAP1-AS1 & $4 p 16.1$ & Up & Oncogene & Antisense & $\begin{array}{l}\text { Inhibit AFAP1 protein expression } \\
\text { and affected the expression of } \\
\text { several small GTPase family } \\
\text { members and molecules in } \\
\text { the actin cytokeratin signaling } \\
\text { pathway. promoted cancer cell } \\
\text { metastasis via regulation of actin } \\
\text { filament integrity }\end{array}$ & [9] \\
\hline Hotair & $12 q 13.13$ & Up & Oncogene & Antisense & $\begin{array}{l}\text { Hotair promoted angiogenesis } \\
\text { through directly activating the } \\
\text { transcription of angiogenic } \\
\text { factor VEGFA as well as through } \\
\text { GRP78-mediated upregulation of } \\
\text { VEGFA and Ang2 expression }\end{array}$ & [8] \\
\hline HNF1A-AS & $12 \mathrm{q} 24.31$ & Up & Oncogene & Antisense & $\begin{array}{l}\text { Promoted proliferation, migration } \\
\text { and EMT }\end{array}$ & {$[37,70]$} \\
\hline IncRNA-LET & $15 \mathrm{q} 24.1$ & Down & $\begin{array}{c}\text { Tumor } \\
\text { suppressor }\end{array}$ & Intronic & $\begin{array}{l}\text { inhibited NPC cells proliferation } \\
\text { and induced cell apoptosis, } \\
\text { transcriptional repressed by } \\
\text { EZH2-mediated H3K } 27 \text { histone } \\
\text { methylation on the LET promoter }\end{array}$ & {$[71]$} \\
\hline H19 & $11 \mathrm{p} 15.5$ & Up & Oncogene & LincRNA & $\begin{array}{l}\text { Inhibited E-cadherin expression } \\
\text { and promoted invasion via the } \\
\text { mir-630/EZH2 pathway }\end{array}$ & {$[54]$} \\
\hline NEAT1 & $11 q 13$ & Up & Oncogene & Sense & $\begin{array}{l}\text { Regulated EMT phenotype and } \\
\text { radioresistance by modulatin } \\
\text { themir-204/ZEB1 axis }\end{array}$ & {$[22]$} \\
\hline MALAT1 & $11 \mathrm{q} 13.1$ & Up & Oncogene & Sense & $\begin{array}{l}\text { Regulated CSC activity and } \\
\text { radioresistance by modulating mir- } \\
1 / \text { slug axis }\end{array}$ & {$[23]$} \\
\hline LOC401317 & NA & Up & Oncogene & NA & $\begin{array}{l}\text { Inhibited cell proliferation and } \\
\text { induced apoptosis }\end{array}$ & {$[10]$} \\
\hline LINC00312 & $3 \mathrm{p} 26$ & Down & $\begin{array}{c}\text { Tumor } \\
\text { suppressor }\end{array}$ & Intergenic & NA & {$[72]$} \\
\hline
\end{tabular}

It was identified that MALAT1 is highly expressed in hepatocellular cancer [18], breast cancer [19], and colorectal cancer [20]. The radio-resistence is a major challenge for NPC radiotherapy. Previous studies showed that lncRNAs has important function in cancer radio-resistance [21, 22].
Recent study demonstrated that MALAT1 regulates radioresistance [23] [24, 25]. It was demonstrated that MALAT1 directly bind to miR-1 in special site $[23,26]$. Chou et al. found that MALAT1 regulate the metastases (migration and invasion) in breast cancer via affecting cdc42 through 
binding mir-1 [26], and which suggested that MALAT1 may regulate migration and invasion of nasopharyngeal carcinoma in similar pathways [27].

However, in renal cell carcinoma, high expression of MALAT-1 and the Livin protein were identified. Moreover, high expression of MALAT-1 leads to cell apoptosis and loss of the cell viability. MALAT-1 induced the high expression of the Livin protein which leads to proliferation and metastasis of renal cell carcinoma $[17,18]$.

\section{HOTAIR}

Transcription of the antisense strand of HoxC gene leads to formation of HOTAIR, located on chromosome 12q13.13. HOTAIR was first reported as a polyadenyated and spliced transcript containing 2158 nucleotide with 6 exons [28]. Yan et al. reported that for nasopharyngeal carcinoma progression and survival, HOTAIR functions as an independent prognostic marker [28]. In previous study, it has showed that highly expressed HOTAIR is correlated with tumors size and clinical stage. In addition, the HOTAIR expression is exponentially increases with progression in clinical stage and finally high expression of HOTAIR is correlated with a poor prognosis of cancer. Moreover, the migration, invasion and proliferation of NPC cells is regulated by the expression of HOTAIR. $\mathrm{Fu}$ et al. found that HOTAIR mediated angiogenesis in NPC by direct and indirect signaling pathways [8]. It has been showed that, HOTAIR is up-regulated in NPC cells and tissues. Interestingly, HOTAIR knockdown causes inhibition of cell growth and angiogenesis. Additionally, HOTAIR, induced VEGFA by either binding to the promoter region of VEGFA or indirectly by GRP78mediated up-regulation of VEGFA and Ang2 expression. Additonally, HOTAIR is a biomarker and therapeutic target for the treatment of NPC.

Presently, the functional mechanisms, regulatory network and pathways of action of HOTAIR remain mostly undiscovered. Recent study showed that HOTAIR interacts with polycomb repressive complex 2 (PRC2). In addition, HOTAIR also regulates chromosome occupancy by EZH2 (a subunit of PRC2). HOTAIR mediates trimethylation of the homeobox D locus by histone $\mathrm{H} 3$ lysine 27 (H3K27). The function of HOTAIR in regulation of chromosome occupancy which in turn enforces a silent chromatin state at Hox gene and other additional genes associated with cancer development and metastasis [28].

\section{AFAP1-AS1}

However, AFAP1-AS1 was hypo-methylated and up-regulated in esophageal cancer by $\mathrm{Wu}$ and his colleagues in 2013 [29]. Later, several studies showed that AFAP1-AS1 was up-regulated and correlated with poor prognosis in different types of cancer [9, 30-36]. Bo et al., also identified that overexpression of AFAP1-
AS1 was directly correlated with development of nasopharyngeal carcinoma [9]. AFAP1-AS1 knockdown causes inhibition of migration and invasive capability of NPC cell, while increased AFAP1 protein expression leads to loss of integrity for induced stress filament. Their data suggests that AFAP1-AS1 is a strong potential biomarker as well as a therapeutic target for the treatment of NPC.

Tumor formation ability of AFAP1-AS1 silenced SW480 cells was significantly suppressed. In addition, we found that AFAP1-AS1 silencing could promote the expression level of AFAP1 protein, a binding partner for oncogenic Src [29], while having no effect on the level of AFAP1 mRNA. AFAP1-AS1 knockdown could induce the loss of stress filament integrity, affecting the expression of Rho/Rac GTPase family members which finally correlated with the actin cytokeratin signaling pathway proteins in nasopharyngeal cancer cells [34-36].

\section{HNF1A-AS}

HNF1A-AS, a lncRNAs, containing 2,455nucleotide with a single exon located at 12q24.31 [37]. It has been showed that HNF1A-AS played an important role in different types of cancers [37-40]. Recently, Zhuang et al. identified that HNF1A-AS is up-regulated and promoted cell proliferation and metastasis in NPC [37]. HNF1AAS knockdown results in inhibition of cell proliferation both in vivo and in vitro. HNF1A-AS-knocdown induced cell get arrested in G0/G1 phase. Moreover, HNF1A-ASknockdown leads to lower expression of EMT biomarkers. Therefore, it provides a new therapeutic strategy for NPC diagnosis and therapy.

\section{LncRNA-LET}

LncRNA-LET is a transcript of 2606 bps length located on 15q24.1. It was reported that lncRNA-LET was down-regulated and acted as a tumor suppressor in several types of cancers [41-44]. Sun et al. reported that the level of lncRNA-LET was significantly decreased in NPC tissues. Moreover, down-regulated lncRNA-LET was directly correlated with size of the tumor, burden of the lymph node which in turn associated with clinical stages and poor survival. LncRNA-LET inhibited the proliferation of the NPC cells but induced cell apoptosis. Hence, IncRNA-LET is playing significant role in nasopharyngeal carcinoma by proliferation of cells and apoptosis through an epigenetic mechanism.

In addition, recent study showed that IncRNAsLET was functionally dysregulated in a variety of tumors. Moreover, the molecular mechanisms are still not clear. However, IncRNA-LET was repressed by hypoxiainduced histone deacetylase 3 through modulation of the lncRNA-LET promoter region [41, 42]. In addition, down-regulation of lncRNA-LET leads to stabilization 
of nuclear factor 90 protein which results into hypoxiainduced cancer cell invasion. Finally, unrevealing the function of lncRNA-LET allow us to open new avenues for therapeutic intervention against nasopharyngeal cancer [44].

\section{H19}

H19 is one of the earliest-discovered and widely studied lncRNAs. Camilynn and his colleagues in 1990, has found that H19 is an imprinted gene [45]. However, $\mathrm{H} 19$ is up-regulated in patients with gastric cancer [46-48], bladder cancer [49], prostate cancer [50], colorectal cancer [51], glioma [52], breast cancer [53]. Recently, Li et al. identified that H19 was also up-regulated in patients with NPC [54]. It has been reported that H19 suppressed the expression of E-cadherin followed by invasion of NPC cells via the mir-630/EZH2 pathway. It has been showed that H19 plays a significant role in metastasis and a therapy target for NPC. However, in the future, more research is required to understand the correlation between the expression of H19 and the development of NPC.

\section{XIST}

In addition, XIST is a spliced lncRNA transcript comprises of $19 \mathrm{~kb}$ nucleotide, transcribed from XIST gene [55-57]. Recent studies have shown that XIST is required for the imprinted and random forms of $\mathrm{X}$ inactivation with gain or loss of function [58-60]. Since last several years, it has showed that XIST is found to be increased in nonsmall cell lung cancer [61], glioblastoma [62]. Recent report found that XIST was up-regulated in NPC tissues and acted as an oncogene [63]. Finally, XIST induced the expression of E2F3 through "spongening" mir-34-5p.

However, XIST interact with two nuclear proteins act as possible RNA chaperones [58, 62].

\section{Potential clinical applications of IncRNAs in NPC}

According to the recent research, lncRNAs are considered as new type biomarkers of disease, as many lncRNAs showed species-specific and tissues-specific expression. In addition, lncRNAs are dysregulated in cancers and other diseases. Moreover, it is found that some lncRNAs are present in body fluid, and this suggests that circulation or secretory lncRNAs plays important roles in diagnosis as biomarkers. Merdan Fayda et al., found that plasma GAS5 could be a biomarker to predict the treatment response in $\mathrm{HNC}$ patients (including nasopharyngeal carcinoma) [64]. Moreover, exosomes are small membrane vesicles containing proteins, mRNA and miRNAs, and it suggests that they have a significant functions in cellular communication [65]. In addition, lncRNAs usually packed into cellular vesicles [66].
Furthermore, Gezer et al. have demonstrated that lncRNAs have a differential abundance in exsomes [67]. They found that several lncRNAs were accumulated in cellular vesicles in MCF7 and Hela cells.

LncRNAs may also be new targets for NPC therapy. As $\mathrm{H} 19$ is an oncogenic lncRNA and upregulated in multiple tumors including NPC, hence, it is a promising alternative therapy target of cancer [68]. H19 may also be a potential therapy target of NPC. Taken together, although only few lncRNAs have been characterized in NPC presently, and the dysregulated lncRNAs will be the most significant factor for the clinical diagnosis and follow-up treatment therapy of NPC.

\section{Summary and prospect}

In this review, we briefly describe both previous and recent studies regarding the association of lncRNAs with NPC. However, expression of lncRNAs and their significant function in development of NPC are quite studied. LncRNA, also has an important function as novel biomarker for the clinical diagnosis and treatment of NPC. In future research, we must concentrate on the function of lncRNAs and their correlation with the development of NPC as well as development of new clinical diagnostic biomarker and therapeutic target of NPC. Most importantly, the clinical trials will be taken to study their effects in humans. In the future, lncRNAs will be the key factor in NPC biology with the effects.

\section{ACKNOWLEDGMENTS}

This work was supported by the grants from the National Natural Science Foundation of China (Grant number 81372825), the China Postdoctoral Science Foundation (2015M582340), the Natural Science Foundation of Hunan Provicne (2016JJ2014), the Education Department Project of Hunan Province (13C882), the Health Department project of the Hunan Province (B2012-157), and the Young Natural Science Foundation of Chenzhou (CZ2013063).

\section{CONFLICTS OF INTEREST}

There is no conflict of interest.

\section{REFERENCES}

1. Chua ML, Wee JT, Hui EP and Chan AT. Nasopharyngeal carcinoma. Lancet. 2015.

2. Chen W, Zheng R, Baade PD, Zhang S, Zeng H, Bray F, Jemal A, Yu XQ and He J. Cancer statistics in China, 2015. CA: a cancer journal for clinicians. 2016.

3. Fang Y, Zhu X, Wang J, Li N, Li D, Sakib N, Sha Z and Song W. MiR-744 functions as a proto-oncogene in 
nasopharyngeal carcinoma progression and metastasis via transcriptional control of ARHGAP5. Oncotarget. 2015; 6:13164-13175. doi: 10.18632/oncotarget.3754.

4. Ponting CP, Oliver PL and Reik W. Evolution and functions of long noncoding RNAs. Cell. 2009; 136:629-641.

5. Riquelme I, Ili C, Roa JC and Brebi P. Long non-coding RNAs in gastric cancer: mechanisms and potential applications. Oncotarget. 2016 May 17. doi: 10.18632/ oncotarget.9396. [Epub - ahead of print].

6. Wapinski $\mathrm{O}$ and Chang HY. Long noncoding RNAs and human disease. Trends in cell biology. 2011; 21:354-361.

7. Gibb EA, Brown CJ and Lam WL. The functional role of long non-coding RNA in human carcinomas. Molecular cancer. 2011; 10:38.

8. Fu WM, Lu YF, Hu BG, Liang WC, Zhu X, Yang HD, Li $\mathrm{G}$ and Zhang JF. Long noncoding RNA hotair mediated angiogenesis in nasopharyngeal carcinoma by direct and indirect signaling pathways. Oncotarget. 2016; 7:4712-23. doi: 10.18632/oncotarget.6731.

9. Bo H, Gong Z, Zhang W, Li X, Zeng Y, Liao Q, Chen P, Shi L, Lian Y, Jing Y, Tang K, Li Z, Zhou Y, et al. Upregulated long non-coding RNA AFAP1-AS1 expression is associated with progression and poor prognosis of nasopharyngeal carcinoma. Oncotarget. 2015; 6:20404-20418. doi: 10.18632/ oncotarget.4057.

10. Gong Z, Zhang S, Zeng Z, Wu H, Yang Q, Xiong F, Shi L, Yang J, Zhang W, Zhou Y, Zeng Y, Li X, Xiang B, et al. LOC401317, a p53-regulated long non-coding RNA, inhibits cell proliferation and induces apoptosis in the nasopharyngeal carcinoma cell line HNE2. PloS one. 2014; 9:e110674.

11. Wang $\mathrm{KC}$ and Chang HY. Molecular mechanisms of long noncoding RNAs. Molecular cell. 2011; 43:904-914.

12. Derrien T, Johnson R, Bussotti G, Tanzer A, Djebali S, Tilgner H, Guernec G, Martin D, Merkel A, Knowles DG, Lagarde J, Veeravalli L, Ruan X, Ruan Y, Lassmann T, Carninci P, et al. The GENCODE v7 catalog of human long noncoding RNAs: analysis of their gene structure, evolution, and expression. Genome research. 2012; 22:1775-1789.

13. Pink RC, Wicks K, Caley DP, Punch EK, Jacobs L and Carter DR. Pseudogenes: pseudo-functional or key regulators in health and disease? Rna. 2011; 17:792-798.

14. Gupta RA, Shah N, Wang KC, Kim J, Horlings HM, Wong DJ, Tsai MC, Hung T, Argani P, Rinn JL, Wang Y, Brzoska P, Kong B, Li R, West RB, van de Vijver $\mathrm{MJ}$, et al. Long non-coding RNA HOTAIR reprograms chromatin state to promote cancer metastasis. Nature. 2010; 464:1071-1076.

15. Tripathi V, Ellis JD, Shen Z, Song DY, Pan Q, Watt AT, Freier SM, Bennett CF, Sharma A, Bubulya PA, Blencowe BJ, Prasanth SG and Prasanth KV. The nuclear-retained noncoding RNA MALAT1 regulates alternative splicing by modulating SR splicing factor phosphorylation. Molecular cell. 2010; 39:925-938.
16. Guttman M and Rinn JL. Modular regulatory principles of large non-coding RNAs. Nature. 2012; 482:339-346.

17. Ji P, Diederichs S, Wang W, Boing S, Metzger R, Schneider PM, Tidow N, Brandt B, Buerger H, Bulk E, Thomas M, Berdel WE, Serve H and Muller-Tidow C. MALAT1, a novel noncoding RNA, and thymosin beta4 predict metastasis and survival in early-stage non-small cell lung cancer. Oncogene. 2003; 22:8031-8041.

18. Lai MC, Yang Z, Zhou L, Zhu QQ, Xie HY, Zhang F, Wu LM, Chen LM and Zheng SS. Long non-coding RNA MALAT-1 overexpression predicts tumor recurrence of hepatocellular carcinoma after liver transplantation. Medical oncology. 2012; 29:1810-1816.

19. Zhang L, Song X, Wang X, Xie Y, Wang Z, Xu Y, You $X$, Liang $Z$ and Cao H. Circulating DNA of HOTAIR in serum is a novel biomarker for breast cancer. Breast cancer research and treatment. 2015; 152:199-208.

20. Yang MH, Hu ZY, Xu C, Xie LY, Wang XY, Chen SY and Li ZG. MALAT1 promotes colorectal cancer cell proliferation/ migration/invasion via PRKA kinase anchor protein 9. Biochimica et biophysica acta. 2015; 1852:166-174.

21. Wang Q, Fan H, Liu Y, Yin Z, Cai H, Liu J, Wang Z, Shao M, Sun X, Diao J, Liu Y, Tong L and Fan Q. Curcumin enhances the radiosensitivity in nasopharyngeal carcinoma cells involving the reversal of differentially expressed long non-coding RNAs. International journal of oncology. 2014; 44:858-864.

22. Lu Y, Li T, Wei G, Liu L, Chen Q, Xu L, Zhang K, Zeng D and Liao R. The long non-coding RNA NEAT1 regulates epithelial to mesenchymal transition and radioresistance in through miR-204/ZEB1 axis in nasopharyngeal carcinoma. Tumour biology. 2016.

23. Jin C, Yan B, Lu Q, Lin Y and Ma L. The role of MALAT1/ miR-1/slug axis on radioresistance in nasopharyngeal carcinoma. Tumour biology. 2015.

24. Huang G, Wu X, Li S, Xu X, Zhu H and Chen X. The long noncoding RNA CASC2 functions as a competing endogenous RNA by sponging miR-18a in colorectal cancer. Scientific reports. 2016; 6:26524.

25. Su Z, Zhi X, Zhang Q, Yang L, Xu H and Xu Z. LncRNA H19 functions as a competing endogenous RNA to regulate AQP3 expression by sponging miR-874 in the intestinal barrier. FEBS letters. 2016; 590:1354-1364.

26. Chou J, Wang B, Zheng T, Li X, Zheng L, Hu J, Zhang Y, Xing $\mathrm{Y}$ and Xi T. MALAT1 induced migration and invasion of human breast cancer cells by competitively binding miR-1 with cdc42. Biochemical and biophysical research communications. 2016; 472:262-269.

27. Wu CD, Kuo YS, Wu HC and Lin CT. MicroRNA-1 induces apoptosis by targeting prothymosin alpha in nasopharyngeal carcinoma cells. Journal of biomedical science. 2011; 18:80.

28. Rinn JL, Kertesz M, Wang JK, Squazzo SL, Xu X, Brugmann SA, Goodnough LH, Helms JA, Farnham PJ, Segal $\mathrm{E}$ and Chang HY. Functional demarcation of active and silent chromatin domains in human HOX loci by noncoding RNAs. Cell. 2007; 129:1311-1323. 
29. Wu W, Bhagat TD, Yang X, Song JH, Cheng Y, Agarwal R, Abraham JM, Ibrahim S, Bartenstein M, Hussain Z, Suzuki M, Yu Y, Chen W, Eng C, Greally J, Verma A, et al. Hypomethylation of noncoding DNA regions and overexpression of the long noncoding RNA, AFAP1-AS1, in Barrett's esophagus and esophageal adenocarcinoma. Gastroenterology. 2013; 144:956-966 e954.

30. Ye Y, Chen J, Zhou Y, Fu Z, Zhou Q, Wang Y, Gao W, Zheng S, Zhao X, Chen T and Chen R. High expression of AFAP1-AS1 is associated with poor survival and short-term recurrence in pancreatic ductal adenocarcinoma. Journal of translational medicine. 2015; 13:137.

31. Deng J, Liang Y, Liu C, He S and Wang S. The up-regulation of long non-coding RNA AFAP1-AS1 is associated with the poor prognosis of NSCLC patients. Biomedicine \& pharmacotherapy $=$ Biomedecine $\&$ pharmacotherapie. 2015; 75:8-11.

32. Zeng Z, Bo H, Gong Z, Lian Y, Li X, Li X, Zhang W, Deng H, Zhou M, Peng S, Li G and Xiong W. AFAP1-AS1, a long noncoding RNA upregulated in lung cancer and promotes invasion and metastasis. Tumour biology. 2016; 37:729-737.

33. Zhou XL, Wang WW, Zhu WG, Yu CH, Tao GZ, Wu QQ, Song YQ, Pan P and Tong YS. High expression of long noncoding RNA AFAP1-AS1 predicts chemoradioresistance and poor prognosis in patients with esophageal squamous cell carcinoma treated with definitive chemoradiotherapy. Molecular carcinogenesis. 2016.

34. Lu X, Zhou C, Li R, Liang Z, Zhai W, Zhao L and Zhang S. Critical role for the long non-coding RNA AFAP1-AS1 in the proliferation and metastasis of hepatocellular carcinoma. Tumour biology. 2016.

35. Zhang JY, Weng MZ, Song FB, Xu YG, Liu Q, Wu JY, Qin $\mathrm{J}$, Jin $\mathrm{T}$ and $\mathrm{Xu}$ JM. Long noncoding RNA AFAP1-AS1 indicates a poor prognosis of hepatocellular carcinoma and promotes cell proliferation and invasion via upregulation of the RhoA/Rac2 signaling. International journal of oncology. 2016; 48:1590-1598.

36. Wang F, Ni H, Sun F, Li M and Chen L. Overexpression of lncRNA AFAP1-AS1 correlates with poor prognosis and promotes tumorigenesis in colorectal cancer. Biomedicine $\&$ pharmacotherapy $=$ Biomedecine $\&$ pharmacotherapie. 2016; 81:152-159.

37. Yang X, Song JH, Cheng Y, Wu W, Bhagat T, Yu Y, Abraham JM, Ibrahim S, Ravich W, Roland BC, Khashab M, Singh VK, Shin EJ, Yang X, Verma AK, Meltzer SJ, et al. Long non-coding RNA HNF1A-AS1 regulates proliferation and migration in oesophageal adenocarcinoma cells. Gut. 2014; 63:881-890.

38. Liu Z, Wei X, Zhang A, Li C, Bai J and Dong J. Long noncoding RNA HNF1A-AS1 functioned as an oncogene and autophagy promoter in hepatocellular carcinoma through sponging hsa-miR-30b-5p. Biochemical and biophysical research communications. 2016; 473:1268-1275.
39. Dang Y, Lan F, Ouyang X, Wang K, Lin Y, Yu Y, Wang L, Wang $\mathrm{Y}$ and Huang Q. Expression and clinical significance of long non-coding RNA HNF1A-AS1 in human gastric cancer. World journal of surgical oncology. 2015; 13:302.

40. Wu Y, Liu H, Shi X, Yao Y, Yang W and Song Y. The long non-coding RNA HNF1A-AS1 regulates proliferation and metastasis in lung adenocarcinoma. Oncotarget. 2015; 6:9160-9172. doi: 10.18632/oncotarget.3247.

41. Yang F, Huo XS, Yuan SX, Zhang L, Zhou WP, Wang F and Sun SH. Repression of the long noncoding RNA-LET by histone deacetylase 3 contributes to hypoxia-mediated metastasis. Molecular cell. 2013; 49:1083-1096.

42. Zhou B, Jing XY, Wu JQ, Xi HF and Lu GJ. Downregulation of long non-coding RNA LET is associated with poor prognosis in gastric cancer. International journal of clinical and experimental pathology. 2014; 7:8893-8898.

43. Jiang S, Wang HL and Yang J. Low expression of long noncoding RNA LET inhibits carcinogenesis of cervical cancer. International journal of clinical and experimental pathology. 2015; 8:806-811.

44. Ma MZ, Kong X, Weng MZ, Zhang MD, Qin YY, Gong W, Zhang WJ and Quan ZW. Long non-coding RNA-LET is a positive prognostic factor and exhibits tumor-suppressive activity in gallbladder cancer. Molecular carcinogenesis. 2015; 54:1397-1406.

45. Brannan CI, Dees EC, Ingram RS and Tilghman SM. The product of the H19 gene may function as an RNA. Molecular and cellular biology. 1990; 10:28-36.

46. Yang F, Bi J, Xue X, Zheng L, Zhi K, Hua J and Fang G. Up-regulated long non-coding RNA H19 contributes to proliferation of gastric cancer cells. The FEBS journal. 2012; 279:3159-3165.

47. Li H, Yu B, Li J, Su L, Yan M, Zhu Z and Liu B. Overexpression of lncRNA H19 enhances carcinogenesis and metastasis of gastric cancer. Oncotarget. 2014; 5:23182329. doi: 10.18632/oncotarget.1913.

48. Chen JS, Wang YF, Zhang XQ, Lv JM, Li Y, Liu XX and Xu TP. H19 serves as a diagnostic biomarker and up-regulation of $\mathrm{H} 19$ expression contributes to poor prognosis in patients with gastric cancer. Neoplasma. 2016; 63:223-230.

49. Luo M, Li Z, Wang W, Zeng Y, Liu Z and Qiu J. Long non-coding RNA H19 increases bladder cancer metastasis by associating with EZH2 and inhibiting E-cadherin expression. Cancer letters. 2013; 333:213-221.

50. Zhu M, Chen Q, Liu X, Sun Q, Zhao X, Deng R, Wang Y, Huang J, Xu M, Yan J and Yu J. lncRNA H19/miR-675 axis represses prostate cancer metastasis by targeting TGFBI. The FEBS journal. 2014; 281:3766-3775.

51. Cui H, Onyango P, Brandenburg S, Wu Y, Hsieh CL and Feinberg AP. Loss of imprinting in colorectal cancer linked to hypomethylation of H19 and IGF2. Cancer research. 2002; 62:6442-6446. 
52. Shi Y, Wang Y, Luan W, Wang P, Tao T, Zhang J, Qian J, Liu N and You Y. Long non-coding RNA H19 promotes glioma cell invasion by deriving miR-675. PloS one. 2014; 9:e86295.

53. Vennin C, Spruyt N, Dahmani F, Julien S, Bertucci F, Finetti P, Chassat T, Bourette RP, Le Bourhis X and Adriaenssens E. H19 non coding RNA-derived miR-675 enhances tumorigenesis and metastasis of breast cancer cells by downregulating c-Cbl and Cbl-b. Oncotarget. 2015; 6:29209-29223. doi: 10.18632/oncotarget.4976.

54. Li X, Lin Y, Yang X, Wu X and He X. Long noncoding RNA H19 regulates EZH2 expression by interacting with miR-630 and promotes cell invasion in nasopharyngeal carcinoma. Biochemical and biophysical research communications. 2016; 473:913-919.

55. Brown CJ, Ballabio A, Rupert JL, Lafreniere RG, Grompe $\mathrm{M}$, Tonlorenzi R and Willard HF. A gene from the region of the human $\mathrm{X}$ inactivation centre is expressed exclusively from the inactive X chromosome. Nature. 1991; 349:38-44.

56. Brown SD. XIST and the mapping of the X chromosome inactivation centre. BioEssays. 1991; 13:607-612.

57. Brown CJ, Hendrich BD, Rupert JL, Lafreniere RG, Xing Y, Lawrence $J$ and Willard HF. The human XIST gene: analysis of a $17 \mathrm{~kb}$ inactive X-specific RNA that contains conserved repeats and is highly localized within the nucleus. Cell. 1992; 71:527-542.

58. Penny GD, Kay GF, Sheardown SA, Rastan S and Brockdorff N. Requirement for Xist in X chromosome inactivation. Nature. 1996; 379:131-137.

59. Marahrens Y, Panning B, Dausman J, Strauss W and Jaenisch R. Xist-deficient mice are defective in dosage compensation but not spermatogenesis. Genes \& development. 1997; 11:156-166.

60. Sado T, Wang Z, Sasaki H and Li E. Regulation of imprinted $\mathrm{X}$-chromosome inactivation in mice by Tsix. Development. 2001; 128:1275-1286.

61. Tantai J, Hu D, Yang Y and Geng J. Combined identification of long non-coding RNA XIST and HIF1A-AS1 in serum as an effective screening for non-small cell lung cancer. International journal of clinical and experimental pathology. 2015; 8:7887-7895.

62. Yao Y, Ma J, Xue Y, Wang P, Li Z, Liu J, Chen L, Xi Z, Teng H, Wang Z, Li Z and Liu Y. Knockdown of long noncoding RNA XIST exerts tumor-suppressive functions in human glioblastoma stem cells by up-regulating miR-152. Cancer letters. 2015; 359:75-86.
63. Song P, Ye LF, Zhang C, Peng T and Zhou XH. Long noncoding RNA XIST exerts oncogenic functions in human nasopharyngeal carcinoma by targeting miR-34a-5p. Gene. 2016.

64. Fayda M, Isin M, Tambas M, Guveli M, Meral R, Altun M, Sahin D, Ozkan G, Sanli Y, Isin H, Ozgur E and Gezer U. Do circulating long non-coding RNAs (lncRNAs) (LincRNA-p21, GAS 5, HOTAIR) predict the treatment response in patients with head and neck cancer treated with chemoradiotherapy? Tumour biology. 2015.

65. Bang $\mathrm{C}$ and Thum T. Exosomes: new players in cell-cell communication. The international journal of biochemistry \& cell biology. 2012; 44:2060-2064.

66. Qi P, Zhou XY and Du X. Circulating long non-coding RNAs in cancer: current status and future perspectives. Molecular cancer. 2016; 15:39.

67. Gezer U, Ozgur E, Cetinkaya M, Isin M and Dalay N. Long non-coding RNAs with low expression levels in cells are enriched in secreted exosomes. Cell biology international. 2014; 38:1076-1079.

68. Smaldone MC and Davies BJ. BC-819, a plasmid comprising the $\mathrm{H} 19$ gene regulatory sequences and diphtheria toxin A, for the potential targeted therapy of cancers. Current opinion in molecular therapeutics. 2010; 12:607-616.

69. Li L, Gu M, Bo Y, Shi S, Shan Y, Bao L and Yiwen Y. Long non-coding RNA ROR promotes proliferation, migration and chemoresistance of nasopharyngeal carcinoma. Cancer science. 2016.

70. Zhuang K, Wu Q, Jin CS, Yuan HJ and Cheng JZ. Long non-coding RNA HNF1A-AS is upregulated and promotes cell proliferation and metastasis in nasopharyngeal carcinoma. Cancer biomarkers. 2015.

71. Sun Q, Liu H, Li L, Zhang S, Liu K, Liu Y and Yang C. Long noncoding RNA-LET, which is repressed by $\mathrm{EZH} 2$, inhibits cell proliferation and induces apoptosis of nasopharyngeal carcinoma cell. Medical oncology. 2015; 32:226.

72. Zhang W, Huang C, Gong Z, Zhao Y, Tang K, Li X, Fan S, Shi L, Li X, Zhang P, Zhou Y, Huang D, Liang F, Zhang X, Wu M, Cao L, et al. Expression of LINC00312, a long intergenic non-coding RNA, is negatively correlated with tumor size but positively correlated with lymph node metastasis in nasopharyngeal carcinoma. Journal of molecular histology. 2013; 44:545-554. 